\title{
Conservation of the endangered Mediterranean tortoise Testudo hermanni hermanni: The contribution of population genetics and historical demography
}

\author{
Saliha Zenboudji a, ${ }^{a}$, Marc Cheylan ${ }^{a}$, Véronique Arnal ${ }^{a}$, Albert Bertolero ${ }^{c}$, Raphael Leblois ${ }^{\mathrm{d}}$, Guillelme Astruc ${ }^{\mathrm{a}}$, \\ Giorgio Bertorelle ${ }^{\mathrm{e}}$, Joan Ll. Pretus ${ }^{\mathrm{f}}$, Mario Lo Valvo ${ }^{\mathrm{g}}$, Giuseppe Sotgiu ${ }^{\mathrm{h}}$, Claudine Montgelard ${ }^{\mathrm{a}, \mathrm{b}}$ \\ a CEFE UMR 5175, CNRS, Université de Montpellier, Université Paul-Valéry Montpellier, EPHE, 1919 route de Mende, 34293 Montpellier Cedex 5, France \\ b Department of Zoology, University of Johannesburg, P.O. Box 524, Auckland Park 2006, South Africa \\ c Associació Ornitològica Picampall de les Terres de l'Ebre, C/La Galera 53, 43870 Amposta, Spain \\ ' INRA, UMR1062 CBGP, F-34988 Montferrier-sur-Lez, France \\ e Department of Life Sciences and Biotechnology, University of Ferrara, via L. Borsari 46, 44100 Ferrara, Italy \\ ${ }^{\mathrm{f}}$ Department of Ecology, University of Barcelona, Spain \\ g Department of Biological, Chemical and Pharmaceutical Sciences and Technologies, University of Palermo, via Archirafi 18, 90123 Palermo, Italy \\ ${ }^{\text {h }}$ Association Zirichiltaggi-Sardinia Wildlife Conservation, s.v. Filigheddu 62/C, 07100 Sassari, Italy
}

\section{A R T I C L E I N F O}

\section{Article history:}

Received 30 June 2015

Received in revised form 14 December 2015

Accepted 7 January 2016

Available online $\mathrm{xxxx}$

\section{Keywords:}

Conservation genetics

Demographic history

Microsatellites

Testudo hermanni

Genetic structure

Conservation issues

\begin{abstract}
A B S T R A C T
Estimating the genetic variation and demographic trends of species in decline is of major concern in conservation genetics. This study contributes to understanding how historical and anthropogenic factors shape the distribution of current genetic diversity in one of the most endangered reptiles in Western Europe, the Hermann's tortoise Testudo hermanni hermanni. We used 17 microsatellite loci, chosen from a pyrosequencing library specifically developed for the subspecies to genotype eight populations distributed over about 30 sample localities covering almost the entire geographic distribution of the sub-species. The population genetic results reflect a very strong genetic structure and identify three major clusters among the Hermann's tortoise in the occidental Mediterranean basin: a continental cluster (Albera in Spain, Var in France and continental Italy), an insular cluster (Corsica, Sardinia and Sicily) and a cluster of mixed lineage (Minorca). Each of the eight studied populations is characterized by only one lineage except for Minorca, in which two lineages were identified. In contrast to what most empirical studies predict, the genetic diversity of the Hermann's tortoise is greater on islands than on the continent. Islands can therefore be considered as genetic sanctuaries with high conservation potential for this species, particularly in Corsica. Historical demographic patterns inferred with a generalized stepwisemutation model (GSM) using maximum likelihood showed significant past demographic changes in only two of the eight sampled populations: a demographic bottleneck was detected in the Albera population (Spain) and a demographic expansion in Corsica (France). In contrast to what was argued in previous studies, these results indicate that the Hermann's tortoise lineage found in Corsica is autochthonous. The origin of both lineages found in Minorca remains speculative. Lastly, our study identifies the six most relevant management units (sensu Moritz, 1994) for conservation purposes on the basis that they represent a significant part of the evolutionary legacy of the species. Some conservation recommendations were proposed, in particular for the most threatened population in Albera.
\end{abstract}

(c) 2016 Elsevier Ltd. All rights reserved.

\section{Introduction}

Conservation biology is an applied science that includes diverse disciplines (Soulé, 1985). Of these, genetics contributes fundamental knowledge concerning the genetic state of populations (both genetic structure and diversity), as well as demographic trends, inbreeding/outbreeding and introgression (Frankham et al., 2009). Consequently, a variety of roles have been identified for the implications of genetics in conservation (see DeSalle and Amato, 2004). According to

\footnotetext{
* Corresponding author at: 1919 route de Mende, 34293 Cedex 5 Montpellier, France. E-mail address: saliha.zenboudji@cefe.cnrs.fr (S. Zenboudji).
}

Shaffer et al. (2015), one of the most direct roles of genetics in informing amphibian and reptile conservation actions involves identifying and managing the human activities that endanger wild populations. They identify three main topics that we feel are particularly relevant: the trade in threatened species, captive breeding, and the design of natural reserves and parks. For several key species, genetics has helped to identify the source of traded species, the reduction in genetic diversity associated with declining populations, and the patterns of movements and reintroductions (Velo-Antón et al., 2011; Welton et al., 2013). Moreover, genetics has contributed to successfully preventing inbreeding and outbreeding depression by creating ex-situ captive breeding programs that mimic natural mating systems, and by managing levels 
of genetic variation to maximize the probability of successful reintroductions into the wild (Austin et al., 2011; Witzenberger and Hochkirch, 2011). At a larger scale, genetics can and should play a critical role in reserve design (Vasconcelos et al., 2012; von der Heyden et al., 2014). Understanding the ecological and evolutionary processes that maintain and generate biodiversity is essential for designing effective natural reserves (Smith and Grether, 2008). Genetics has been used to define many types of conservation units, such as evolutionarily significant units (ESUs) and management units (MUs, Moritz, 1994), and measures such as phylogenetic diversity (PD, Winter et al., 2013). These have all been proposed as critical tools in identifying the most important landscapes for protection as they can help to capture evolutionary processes (Faith, 2008; Smith and Grether, 2008).

The contraction of a species' geographic range as a consequence of habitat fragmentation constitutes a major threat to its diversity (Young and Clarke, 2000; Freeland et al., 2011). Fragmentation increases the isolation of populations in sparse remnant patches, causing a decrease in population size often referred to as a population bottleneck. Its main consequence is the loss of alleles through genetic drift leading to a reduction in genetic diversity (Bouzat, 2010; Frankham et al., 2009). In the long term, completely isolated population fragments will suffer elevated rates of inbreeding due to reduced gene flow between populations. This negative spiral, leading ultimately to the disappearance of a population, has been named the "extinction vortex" (Frankham et al., 2009). For the management of populations, effective population size $(\mathrm{Ne})$ is a critical piece of information (Frankham, 2007). Because reptiles and amphibians are often difficult to count in the wild, direct estimates of the number of breeding individuals are rare (Shaffer et al., 2015). The application of genetic methods can not only help to estimate the effective breeding size of a population, but for several species also offers a valuable alternative that allows the historical patterns of population expansion or decline to be inferred (Funk et al., 1999; Phillipsen et al., 2011; Casas-Marce et al., 2013; Kamath et al., 2015). From a conservation perspective, the identification of demographic bottlenecks is crucial because these lessen the chance of survival of populations that have undergone significant declines (Peery et al., 2012). The quantification of genetic variation and demographic trends in declining and/or fragmented species is a major concern in conservation genetics studies (Lozier, 2014) since the evolutionary potential and, ultimately, the persistence of a species depend, among other things, on its ability to maintain genetic diversity (Frankham et al., 2009; Lozier, 2014).

Dramatic declines in the abundance of numerous species, particularly reptile species, have been driven by historical climatic events as well as several anthropogenic and ecological factors. These include landscape transformation, environmental fluctuation and demographic stochasticity (Collins and Storfer, 2003; Araújo et al., 2006; Bouzat, 2010; Böhm et al., 2013). This study focuses on the genetic diversity and demographic history of one of the most endangered reptiles in Europe, the western Hermann's tortoise Testudo hermanni hermanni Gmelin, 1789. The Hermann's tortoise is distributed in the Mediterranean region (Fig. 1). Two subspecies have been described by Wermuth (1952) on the basis of morphology and coloration patterns: Testudo hermanni boettgeri mainly occupies the Balkans, where it has a large and more or less continuous distribution that extends to north-eastern Italy; whereas T. h. hermanni occupies the western part of Europe in isolated populations (Cheylan, 2001; Bertolero et al., 2011). These two subspecies are separated by the plain of the Po River in northeastern Italy. The fragmented distribution of $T$. h. hermanni is mainly due to anthropic pressures resulting from habitat destruction and overharvesting, as well as to climate fluctuations of the Quaternary period that have reduced population ranges in refuges located on the northern fringe of the Mediterranean Sea (Cheylan, 1981; Morales Pérez and Sanchis Serra, 2009). Due to its marked decline throughout most of its distribution range (Cheylan, 1984; Bertolero et al., 2011; Cheylan et al., 2011), T. h. hermanni was classed as 'endangered' on the IUCN Red List (European Reptile and Amphibian Specialist Group, 1996) 20 years ago. Subsequently, the Var (France) and Albera (Spain) populations were also classified as 'endangered' on the French and Spanish Red Lists (Llorente et al., 2002; UICN France et al., 2015). In contrast, the populations of T. h. hermanni in Corsica and the Balearic Islands seem to show good demographic dynamism (Cheylan, 1995; Bertolero, 2014a).

Practical conservation measures to protect $T$. $h$. hermanni have mostly been undertaken where the species is identified as vulnerable

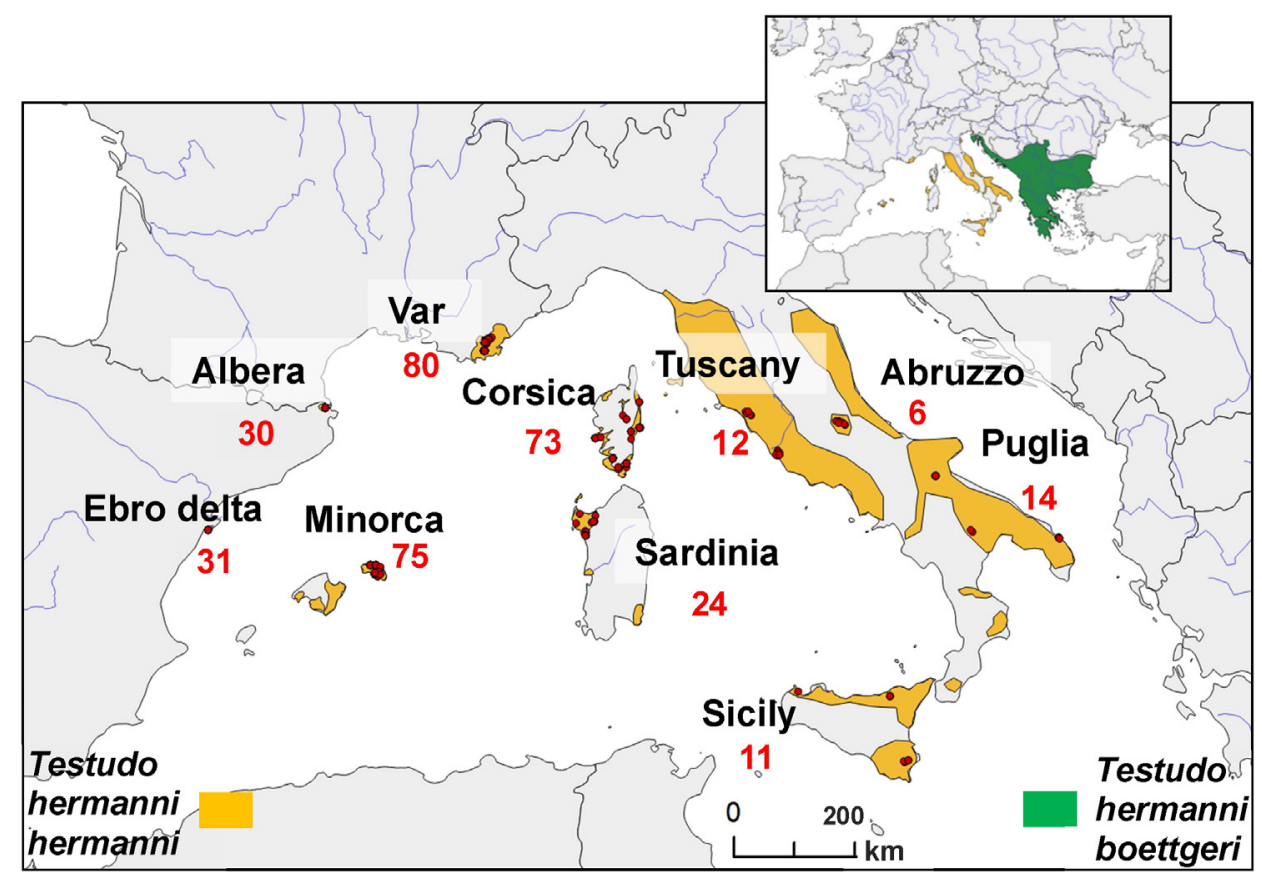

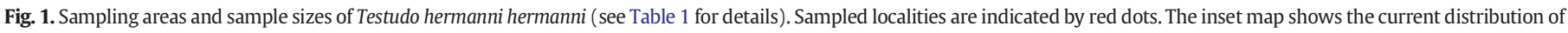

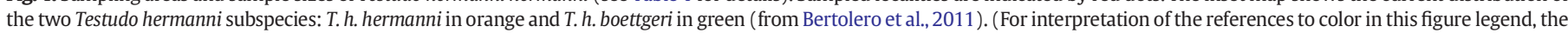
reader is referred to the web version of this article.) 
or endangered (Bertolero, 2010a; Celse et al., 2014); several nature reserves have been created to protect their populations in the Natura 2000 network established around Europe. However, the current network of reserves reproduces the highly fragmented pattern of their distribution. In species with limited dispersal abilities, which is the case of $T$. $h$. hermanni, these reserves may become genetic ghettos for small populations that do not harbor sufficient genetic variation. For these species, the restoration of populations cannot be achieved through natural migration, and other conservation measures are needed. For example, conservation management initiatives for T. h. hermanni populations have included reintroduction projects, breeding programs and reinforcement actions (Bertolero et al., 2011). Most of these have been carried out in Spain by regional governments with the involvement of NGOs (Bertolero, 2010a, 2014a) and in France where translocation actions have been carried out between 1986 and 1998 by SOPTOM, an association for the protection of the Hermann's tortoise (Devaux, 1990; Devaux and Stubbs, 1997). Equally, illegal releases are known to have taken place. Up to the current time, tortoises for translocation or breeding programs have been selected by phenotypic coloration and morphology or by known origin, without any genetic guidance or control. Thus, there is some risk of admixture with $T$. h. boettgeri (sold in larger numbers as pets) or outbreeding depression through the disruption of co-adapted gene complexes (Moritz, 1994) if released tortoises belong to different subspecies or genetic lineages.

Although most continental populations of $T$. $h$. hermanni are native, some populations are the result of reintroduction, such as in the Ebro Delta (Spain) (Bertolero et al., 2007). The origin (native or introduced) of $T$. $h$. hermanni on Mediterranean islands is debated and has been the subject of several studies based on mitochondrial and nuclear markers (Giacalone et al., 2009; Perez et al., 2013). It is considered that T. h. hermanni is native to Sicily (Kotsakis, 1980; Delfino and Chesi, 2008) and was introduced in the Balearic Islands by prehistoric humans during the Neolithic period (Alcover and Mayol, 1981). The question remains open in Corsica and Sardinia, though tortoise fossils that date prior to human occupation have been found on both islands (Hervet and Salotti, 2000; Morales Pérez and Sanchis Serra, 2009).

In this context, our study seeks to apply genetics information to conservation biology and is particularly concerned with Frankham's number 1 priority (Frankham, 2010, p. 663): "Institute rational genetic management of threatened species in the wild, especially for fragmented populations". The objectives of our study were to (i) reveal the number of genetic units in the occidental Mediterranean basin and delimit their spatial geographic boundaries, (ii) determine the origin of the different populations (native versus introduced), (iii) estimate the level of genetic diversity and differentiation within and between groups, (iv) infer temporal demographic changes in effective population sizes, (v) detect the intensity of hybridization with the Balkan subspecies resulting from illegal releases, and (vi) contribute to defining the management and conservation strategies implemented for this species in Europe. To answer these questions, we used 17 microsatellite markers and exhaustive sampling covering almost the entire range of the subspecies, including populations in Albera, Minorca and Sardinia that were absent from previous studies. We also evaluated the relevance of our findings in terms of the conservation implications for the species, in particular concerning the definition of management units (sensu Moritz, 1994).

\section{Material and methods}

\subsection{Sampling and DNA extraction}

Our sampling covered the entire range of the subspecies T. h. hermanni. A total of 357 individuals were analyzed in sample localities throughout the range: 30 individuals from Albera (Spain), 31 from the Ebro Delta (Spain), 75 from Minorca (Spain), 81 from Var (France), 73 from Corsica (France), 24 from Sardinia (Italy), 11 from Sicily (Italy) and 32 from continental Italy (Tuscany, Abruzzo and Puglia) (see Fig. 1 and Table 1). Fifteen $T$. $h$. boettgeri tortoises were added to the analysis to identify potential hybrids between the two subspecies. These $T$. $h$. boettgeri samples were collected at the headquarters of SOPTOM, an association for the protection of the Hermann's tortoise (Station d'Observation et de Protection des Tortues et de leurs Milieux) in Gonfaron, France. The exact geographical origin in the former Yugoslavia was known for only three of these $T . h$. boettgeri tortoises, so this was used as the reference for the boettgeri samples. For each tortoise, $200 \mu \mathrm{l}$ of blood was collected from the nape or coccygeal vein and conserved in a saline solution (Queen buffer). Genomic DNA was then extracted using the DNeasy Blood and Tissue Kit (Qiagen) following the manufacturer's procedure.

\subsection{Microsatellite analysis}

A microsatellite library of 147 markers was specifically developed for $T$. h. hermanni by the biotechnology company Genoscreen (Lille, France) using the method of high-throughput pyrosequencing (GS FLX®, Roche Diagnostics $\left.{ }^{\circledR}\right)$. From this, 15 polymorphic markers were selected for genetic analysis (Zenboudji et al., in prep). We added two polymorphic microsatellite loci (Test10, Test56) characterized for T. hermanni by Forlani et al. (2005). The 17 microsatellite loci were amplified and sequenced in six multiplexes (Zenboudji et al., in prep).

Multiplexed polymerase chain reactions (PCRs) were conducted in a $10 \mu \mathrm{l}$ reaction volume containing $2 \mu \mathrm{l}$ of $\mathrm{H}_{2} \mathrm{O}, 5 \mu \mathrm{l}$ of the Master Mix solution from Qiagen, $1 \mu \mathrm{l}$ of each multiplexed primer at $2 \mu \mathrm{M}$ and $1 \mu \mathrm{l}$ of DNA. All microsatellite loci were run with the following cycling initiated by a denaturation step of $15 \mathrm{~min}$ at $95^{\circ} \mathrm{C}$ followed by 30 cycles of denaturation $\left(30 \mathrm{~s}\right.$ at $94^{\circ} \mathrm{C}$ ), annealing ( $1 \mathrm{~min} 30 \mathrm{~s}$ ), elongation ( $1 \mathrm{~min}$ at $72{ }^{\circ} \mathrm{C}$ ), and ending with a final elongation step of $30 \mathrm{~min}$ at $60^{\circ} \mathrm{C}$. PCR products were genotyped on a 16 capillary sequencer (3130xl Genetic Analyzer, Applied Biosystems) using the "Genotypage-Séquençage" platform at the CeMEB LabEx (Montpellier, France).

Electropherograms were visualized using GeneMapper version 4.5 (Applied Biosystems). Two independent readings were performed by two different people in order to minimize genotyping errors. MicroChecker v.2.2.3 (Van Oosterhout et al., 2004) was used to check for the presence of null alleles for each sample locality.

\section{Table 1}

Genetic diversity indices within each studied population of Testudo hermanni hermanni ( $N$ : sample size; $A R$ : allelic richness; $A P$ : number of private alleles; $H_{o}$ : observed heterozygosity; $H_{e}$ : expected heterozygosity). Statistically significant $F_{i s}$ values are indicated by asterisks: ${ }^{*} \mathrm{p}<0.05,{ }^{* *} \mathrm{p}<0.01,{ }^{* * *} \mathrm{p}<0.001$.

\begin{tabular}{lrrrrrr}
\hline & $N$ & $A R$ & $A P$ & $H_{o}$ & $H_{e}$ & \multicolumn{1}{c}{$F_{i s}$} \\
\hline Continental populations & & & & & & \\
Italy total & 32 & 4.9 & 12 & 0.45 & 0.43 & -0.06 \\
Puglia & 14 & 3.4 & 5 & 0.41 & 0.39 & 0.02 \\
Abruzzo & 6 & 3.2 & 0 & 0.56 & 0.47 & -0.04 \\
Tuscany & 12 & 3.6 & 1 & 0.45 & 0.46 & -0.06 \\
Var (France) total & 81 & 3.8 & 2 & 0.25 & 0.32 & $0.25^{*}$ \\
Var1 & 60 & 2.6 & 4 & 0.24 & 0.25 & $0.11^{* * *}$ \\
Var2 & 16 & 2 & 2 & 0.22 & 0.24 & $0.11^{*}$ \\
Albera (Spain) & 30 & 2 & 1 & 0.17 & 0.22 & $0.2^{* * *}$ \\
Ebro Delta (Spain) & 31 & 3.9 & 0 & 0.41 & 0.40 & -0.01 \\
& & & & & & \\
Insular populations & & & & & & \\
Minorca total & 75 & 3.3 & 0 & 0.33 & 0.38 & $0.14^{* * *}$ \\
Minorca1 & 35 & 3 & 0 & 0.27 & 0.30 & $0.1^{* * *}$ \\
Minorca2 & 40 & 3.2 & 0 & 0.38 & 0.39 & $0.03^{*}$ \\
Corsica total & 73 & 4.4 & 11 & 0.34 & 0.39 & $0.1^{* * *}$ \\
Corsica1 & 39 & 2.7 & 1 & 0.33 & 0.32 & -0.01 \\
Corsica2 & 25 & 3.8 & 14 & 0.35 & 0.36 & 0.04 \\
Corsica3 & 9 & 2.7 & 7 & 0.33 & 0.33 & 0.06 \\
Sardinia & 24 & 4.3 & 3 & 0.39 & 0.4 & 0.03 \\
Sicily & 11 & 3.4 & 4 & 0.38 & 0.38 & 0.05 \\
Thermanni boettgeri & 15 & 4.5 & 10 & 0.43 & 0.49 & $0.15^{*}$ \\
\hline
\end{tabular}




\subsection{Genetic diversity within populations}

The level of genetic variation within each sampled group was measured by GenAlEx v 6.3 (Peakall and Smouse, 2006) using several indices: the allelic richness ( $A R$, for a sample size of $\mathrm{N}=11)$, the number of private alleles $(A P)$, the observed heterozygosity $(\mathrm{Ho})$, the expected heterozygosity (He; Nei, 1978) and the inbreeding coefficient $\left(F_{I S}\right.$; Wright, 1978). Global Hardy Weinberg tests (HW) were performed using Genepop v.4.0.10 (Rousset, 2008) with a Markov chain dememorization of 10,000, 100 batches and 10,000 iterations per batch.

\subsection{Identification of homogenous genetic units}

The number of genetic units within the subspecies $T$. $h$. hermanni was evaluated using the Bayesian clustering method implemented in Structure v. 2.3.1 (Pritchard et al., 2000). This software estimates the likelihood of a specific number of homogenous genetic clusters $(K)$ in the dataset, and the relative contribution of each individual to each cluster, without a priori knowledge of the individual's geographical location. The data was analyzed under the admixture model with a Monte Carlo Markov Chain (MCMC) run of $2.5 \times 10^{6}$ iterations and a burn-in period of $6.5 \times 10^{5}$ for K varying from 1 to 18 . For each value of K, 29 runs were performed to test the MCMC convergence. The most likely number of genetic groups was estimated directly using the resulting likelihood, as well as by the Evanno's method (Evanno et al., 2005).

The spatial genetic structure was described using the clustering analysis implemented in the software BAPS v 4.14 (Corander et al., 2008). We employed the spatial model option, using the geographical coordinates of the individuals belonging to each population unit to be clustered. Identical color or particular tessellation cells were inferred using both molecular data and a spatial prior distribution. 1 to 5 clusters were tested and the spatial model was fitted using 1000 iterations to estimate the admixture coefficient for each sample with 20 replicate runs.

\subsection{Divergence and relationships between populations}

The level of genetic divergence between groups (sampled populations as well as inferred genetic clusters) was estimated by calculating the pairwise $F_{S T}$ (Wright, 1978) according to Weir and Cockerham (1984) using FSTAT v 2.9.3.2 (Goudet, 2001). The significance of the $F_{S T}$ values (i.e. $\neq 0$ ) was tested using 1000 permutations. On the basis of the pairwise $F_{S T}$ matrix, a neighbor-joining (NJ) tree was constructed using the software Population 1.2.28 (Langella, 1999), and the robustness of nodes was tested with 500 bootstrap replications. Based on the genetic clusters revealed by Structure, an analysis of molecular variance (AMOVA) was performed using GenAlEx v 6.3 (Peakall and Smouse, 2006) in order to quantify the fraction of total genetic variance between genetic populations and to characterize the hierarchical distribution of genetic variation between and within populations. The percentage of the variation between populations as well as between individuals within populations was calculated. p-Values of F-statistics were estimated after 999 permutations.

\subsection{Past demography dynamics}

Demographic changes in effective population sizes and the time frame in which these changes occurred were estimated using the program Migraine Version 0.4.1 (Leblois et al., 2014, http://kimura.univmontp2.fr/ rousset/Migraine.htm). To infer model parameters, Migraine uses the class of importance sampling algorithms (IS) developed by De Lorio and Griffiths (2004a, 2004b), De Lorio et al. (2005) and extended in Leblois et al. (2014). As it employs a generalized stepwise-mutation model (GSM) for microsatellite loci, this method is of particular interest compared to other frequently used alternative programs such as MSVAR (Beaumont, 1999; Leblois et al., 2014). Migraine provided estimates of three parameters of interest: ancestral $\theta_{\text {anc }}=4 N_{\text {anc }} \mu$, actual $\theta_{\text {act }}=4 N_{a c t} \mu$, and $D=T / 4 N_{\text {act }}$, where $N_{\text {act }}$ is the current effective population size, $N_{\text {anc }}$ is the ancestral population size (before the demographic change), $T$ is the time measured in generations since the present, and $\mu$ is the mutation rate per locus per generation. The demographic model we used in Migraine considered an exponential change of a population's size starting at $T$ and continuing up to the present. To characterize the strength of the demographic events, we used the extra parameter $N_{\text {ratio }}=N_{a c t} / N_{a n c}$, which is $<1$ in the case of a reduction in size and $>1$ in the case of an expansion. A significant $N_{\text {ratio }}$ was determined when 1 lay outside its 95\% confidence intervals (CIs) (Leblois et al., 2014). Migraine runs were done using 20,000 trees, 2400 points and 3-9 iterations. To translate the parameters inferred from Migraine into effective population size $(N)$ and the timing of the event in generations $(T)$, we applied two mutation rates: the first is the commonly used mutation rate for microsatellites, $\mu=5 \times 10^{-4}$ (Sun et al., 2012), and the second is consistent with the previously reported rate for herpetofauna and long-lived vertebrates, $\mu=$ $1.5 \times 10^{-3}$ (Zhang and Hewitt, 2003). To convert the timing to years, we defined the generation time of $T$. h. hermanni as a period of 15 years.

\section{Results}

\subsection{Genetic diversity within populations}

In total, 148 alleles were scored for the 17 loci in the entire T. hermanni dataset (372 samples). The number of alleles per microsatellite locus ranged from 2 to 22 alleles. Tests for HW equilibrium did not show significant deviation from the expected frequencies in any populations, and no linkage disequilibrium was detected among loci. A summary of genetic diversity indices $\left(A R, A P, H_{o}, H_{e}\right)$ based on the 17 loci is presented in Table 1. Mean allelic richness per population $(A R)$ varied between 2 and 4.9, whereas observed $\left(H_{o}\right)$ and expected $\left(H_{e}\right)$ heterozygosities per population ranged from 0.17 to 0.56 and from 0.22 to 0.49 , respectively.

All T. h. hermanni insular populations showed comparable and high genetic diversity (AR and $H_{o}$, Table 1 ) whereas continental populations were more contrasted: the populations in Italy and Albera presented respectively the highest and lowest values for these indices (Table 1).

The mean fixation index $F_{I S}$ presented significant values for most localities except for those in mainland Italy (Abruzzo, Tuscany and Puglia), Sardinia, Sicily and the Ebro Delta. A deficit in heterozygotes with significant $F_{I S}$ values was noted for the populations in the Var $\left(F_{I S}=0.25\right)$, Albera $\left(F_{I S}=0.2\right)$, Minorca $\left(F_{I S}=0.14\right)$ and Corsica $\left(F_{I S}=0.1\right)$, which persisted in the subgroups Var1, 2 and Minorca1, 2, but not in Corsica1, 2, 3.

\subsection{Identification of population units}

Bayesian clustering assignment, on all individuals of both subspecies (372 samples), revealed that $\mathrm{Ln} \mathrm{L}(\mathrm{K})$ increased with the number of clusters tested ( $\mathrm{K}$ ) and reached a plateau at $\mathrm{K}=10$ groups (Fig. $2 \mathrm{C}$ ). A strong structure for $\mathrm{K}=4$ was detected, corresponding to the highest value of the delta (K) (Fig. 2C). The four clusters differentiate the T. $h$. boettgeri individuals (Fig. 2A) and three clusters of T. $h$. hermanni: the first one consists of the populations in Albera, Var, continental Italy and one part of the island of Minorca, the second group include populations of three islands (Corsica, Sicily and Sardinia), and the third group consists of the populations of the other part of Minorca and the Ebro Delta. This analysis also revealed that several T. h. hermanni individuals show signs of introgression with $T$. h. boettgeri, mainly in three populations: Var, continental Italy (especially in the Abruzzo locality) and the Ebro Delta. Moreover, half of the samples from Minorca are the result of introgressions between the two lineages found on the island.

Based on the likelihood values, the result of $\mathrm{K}=8$ seems to be the most stable (Fig. 2B), considering the large standard deviations of 

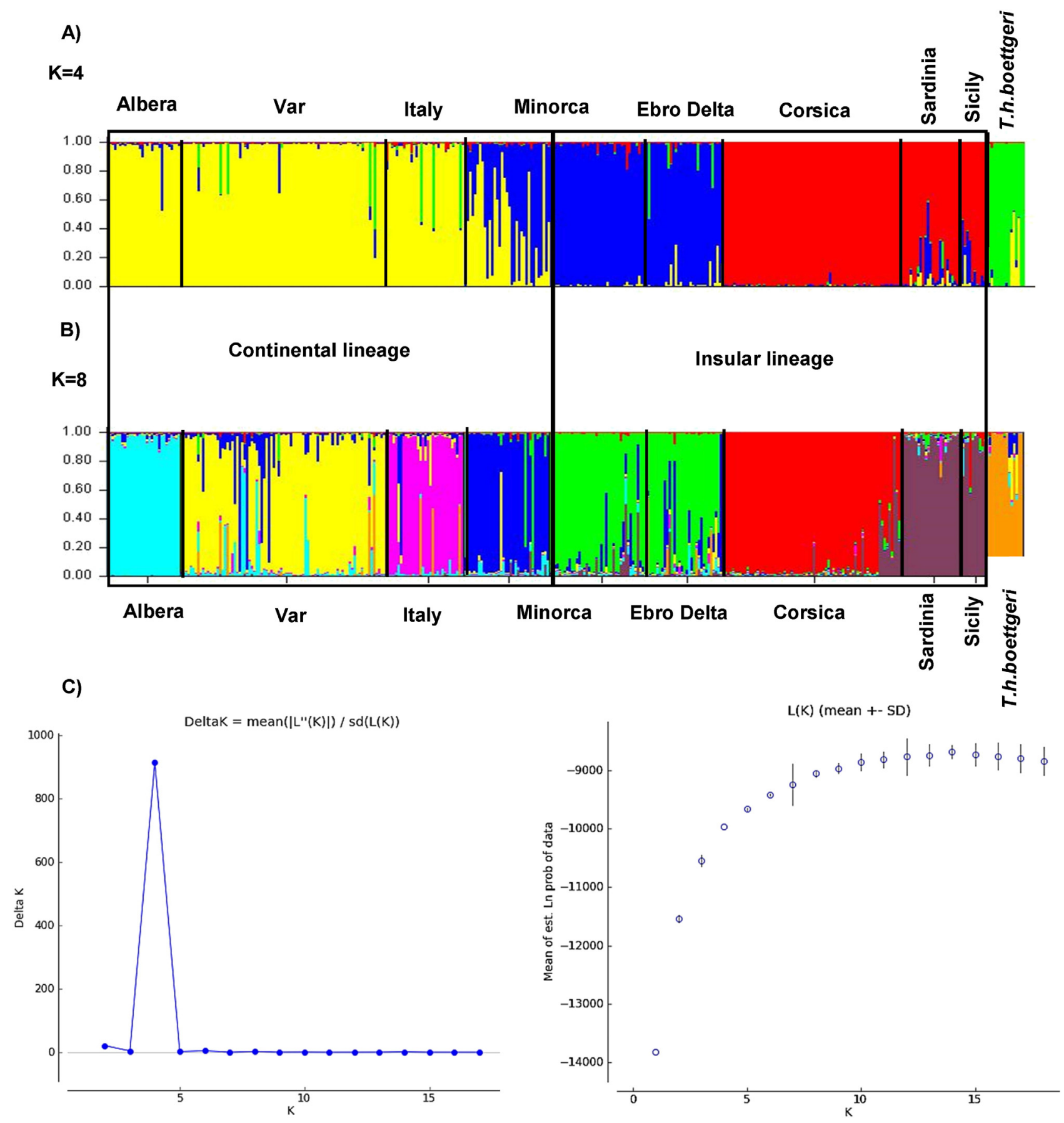

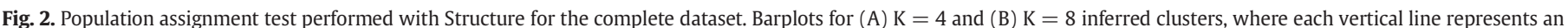

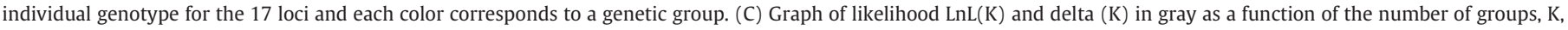
(Evanno's method).

likelihood values from $K=9$ to $K=18$. For $K=8$, of the 29 repetitions performed, 21 had the same result (Fig. 2B). This analysis also identified the group T. h. boettgeri and showed a split within continental and insular lineages of $T$. h. hermanni structured in seven more or less homogeneous clusters. These seven groups are structured geographically and correspond to (1) Albera, (2) Var, (3) continental Italy, (4) Corsica, (5) Sardinia and Sicily; the population of Minorca included two well-differentiated groups, (6) Minorca1 and (7) Minorca2 and Ebro Delta. Minorca1 seems to form a more or less homogeneous group. However, some individuals are primarily admixed with those of Minorca2. The latter formed a single cluster with Ebro Delta. Except for Albera, where the rate of introgression is very low, all other groups showed the presence of admixed individuals (see Section 4.3). Some individuals from continental Italy showed signs of admixture, mainly with the populations from the Var as well as Albera. In Corsica, about ten individuals, mainly from the region of Ajaccio, are highly introgressed with the group Sardinia + Sicily. The reintroduced population in the Ebro Delta displayed the highest proportion of introgression with all other populations.

The spatial distribution patterns of genetic diversity yielded no spatial structure in Italy, Albera, Sardinia or Sicily. In the Var, as in the Structure analysis (Fig. 2B) where it appeared rather heterogeneous, the spatial clustering analyses clearly showed the existence of two genetic subunits (Fig. 3C) that are not geographically structured since 
both groups are present in the Plaine des Maures or in a more remote part of the massif (Lambert). The first cluster (Var1 in Fig. 3C) included the most samples (80\%) and thus possibly represents the local genetic lineage. The other cluster (Var2 in Fig. 3C) contained only 16 samples and is significantly divergent from all other groups tested $\left(F_{S T}>0.3\right.$, see Table A1 and Fig. A1).

In Corsica, three genetic subunits were evidenced (Fig. 3B) that are fully consistent with the geography of the island. A first group is located along the eastern plain (and the center of the island, in the Corte region). A second cluster includes the southern localities of Sartène, Figari and Porto Vecchio. The third group contains samples from the area around Ajaccio and includes tortoises that show signs of introgression with the Sardinia + Sicily lineage (Fig. 2B).

In Minorca (Fig. 3A), the analysis provided the same result as Structure (Fig. 2B): that is, two groups, one corresponding to the western part of the island (Minorca1) and the other located in the eastern part of the island (Minorca2). Genetic diversity indices were revalued for the seven clusters detected in the Var, Corsica and Minorca (Table 1). The heterozygosity values were quite similar to previous estimates. However, we noticed a considerable decrease in the $F_{I S}$ values for all populations, certainly due to the disappearance of the Wahlund effect. In Corsica, the $F_{I S}$ values were not significant, suggesting that the three subunits are in panmictic equilibrium. In contrast, they remain significant for both groups in the Var and Minorca.

\subsection{Differentiation between populations}

The pairwise $F_{S T}$ between the $T$. $h$. hermanni clusters varies from $F_{S T}=0.04$ between the Ebro Delta vs Minorca2 to $F_{S T}=0.58$ between Corsica1 vs Var2 (Table A1B). The test of differentiation with permutations shows that all $F_{S T}$ values are significantly larger than zero $(\mathrm{p} \leq 0.01)$, thus indicating that all populations are very well differentiated. The NJ tree based on $F_{S T}$ values (Fig. A1) was rooted with $T$. $h$. boettgeri and shows that all insular populations and the population of the Ebro Delta clustered in a well-supported group $(\mathrm{BP}=90)$. This corroborates the results from Structure and shows that the Italian populations have a basal position in the tree.

The analysis of molecular variance based on the 14 groups identified for $T$. h. hermanni revealed that the highest percentage of variation was partitioned within populations (62\%) compared to the variation between populations (30\%) and individuals ( $8 \%$; Table A2). The fixation index showed a highly significant genetic structure $\left(F_{S T}=0.31\right.$; $\mathrm{p}<0.05$ ). This result corroborates the strong structuring highlighted by the Bayesian clustering analysis from Structure.

\subsection{Demographic dynamics of the populations}

According to the $N_{\text {ratio }}$ estimates produced by Migraine, only two of the eight sampled populations showed significant demographic changes

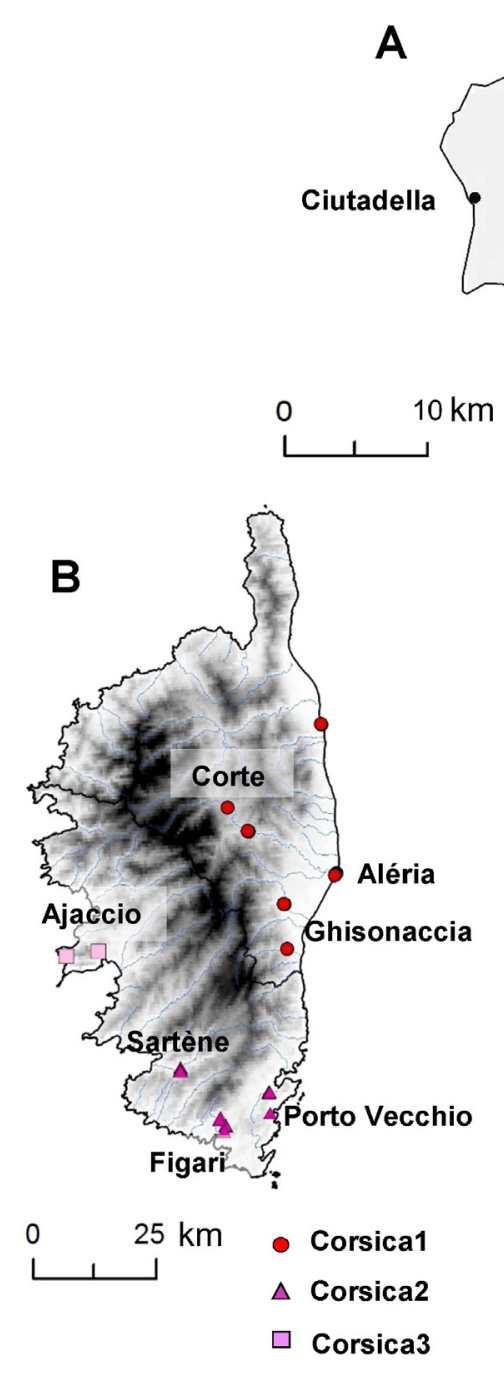

- Minorca
Minorca2

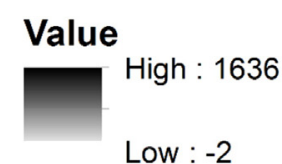

Low : -2

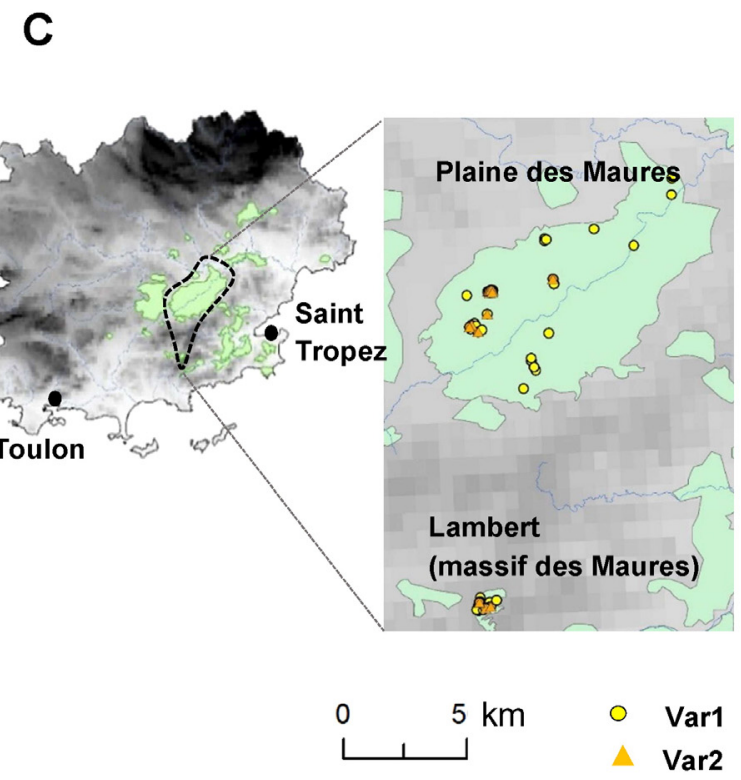

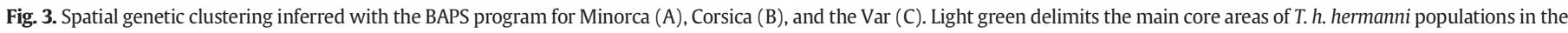

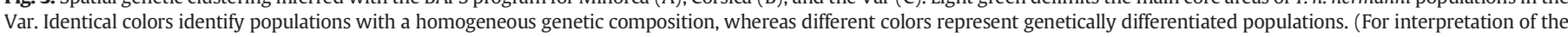
references to color in this figure legend, the reader is referred to the web version of this article.) 
in the past: a bottleneck was detected in the population from Albera and an expansion in the population from Corsica (Table 2, Fig. 4). Migraine detected a highly significant decrease in the effective population size of the Albera population with a current $N_{\text {act }}$ value of only 75 (or 25 with $\mu_{2}=1.5 \times 10^{-3}$ ), whereas the corresponding ancestral $N_{a n c}$ value is 5000. This bottleneck is very ancient and likely occurred around 1200 generations ago, i.e. approximately $19 \mathrm{kyr}$ ago (see Table 2 ). In contrast, the effective population size in Corsica is about 50 times greater now than in the past. Although the $\mathrm{CI}$ values are very large, the timing since the beginning of this expansion is about 200 years, indicating that the expansion is probably relatively recent. For the seven remaining populations, the large $95 \% \mathrm{CI}$ values of the $N_{\text {ratio }}$ indicate stability.

\section{Discussion}

\subsection{High genetic structure in T. h. hermanni}

There is evidence of the presence of $T$. h. hermanni in Western Europe since the Plio-Pleistocene limit. The fossil record suggests that its distribution range between 100,000 and 30,000 years ago extended continuously from Portugal to Italy (Cheylan, 1981; Delfino and Bailon, 2000; Morales Pérez and Sanchis Serra, 2009). Since then, two major causes have affected its range by reducing favorable habitats: the first is Quaternary climatic fluctuations, and the second, more recent, factor is human impacts such as agricultural practices, urbanization, human-related forest fires and poaching (Cheylan, 2004; Bertolero et al., 2011; Couturier et al., 2011; Santos and Cheylan, 2013). Another anthropogenic threat is the illegal and uncontrolled release of tortoises (mainly since 1970), as well as reinforcement programs using captive tortoises of unknown origin. Such displacements have occurred not only in different $T$. h. hermanni populations, but also concern animals from the Balkan subspecies $T$. $h$. boettgeri, which have been sold in large numbers as pets. In this study we assess the relative importance of these factors in explaining the pattern of genetic variability and differentiation observed between the three major lineages of $T$. $h$. hermanni that we have identified on the basis of 17 polymorphic microsatellite loci.

\subsubsection{The continental lineage: Spain (Albera), France (Var) and Italy}

One of the three identified lineages includes the three continental populations of Albera, Var, and peninsular Italy (Fig. 2A). Among all the studied populations, the Albera showed the lowest genetic diversity for all indices (the lowest number of alleles and private alleles and the lowest observed heterozygosity; Table 1). This result is in line with other ecological data indicating its alarming demographic situation (Mascort, 1997; Bertolero, 2010b; Bertolero et al., 2011). Firstly, this population currently occupies a limited geographical area of less than $150 \mathrm{~km}^{2}$, which is fragmented into small patches. Moreover, in the last 30 years, marked signs of decline have been evidenced by very low population densities ( 0.3 individuals/ha for the whole distribution range, Bertolero, 2014b, and 0.6 in the core area, Couturier et al., 2014), as well as contraction of the surface area of the distribution range, mainly due to forest fires, habitat destruction, illegal harvesting and intense predation by carnivores and wild boar, particularly impacting juveniles and nests (Vilardell et al., 2012). According to several studies, the current low density that characterizes this population indicates that it is rather close to extinction (Budó et al., 2004; Bertolero, 2010a, 2010b). This conclusion is corroborated by the significant demographic bottleneck our results show for this population $\left(N_{\text {anc }}=5000\right.$ and $N=75$, Fig. 4; see Section 4.2).

The only French continental population (Var) presented an intermediate diversity level between the Italian and Spanish (Albera) populations (see Table 1) and appeared rather heterogeneous in the Structure analysis (Fig. 2B). This is clearly evidenced in the spatial clustering analyses, which revealed two different genetic groups in the Var (Fig. 3C). However, no geographical structure for these different groups was observed, as both are present in the massif (Lambert) and in the Plaine des Maures. A possible explanation for the presence of the minority group might be the release of tortoises originating from a continental locality that was not sampled in this study or a currently extinct population. Another hypothesis is that the two mitochondrial haplotypes found in the Var for the ARNr 12S gene (Perez et al., 2013) might correspond to the two genetic clusters in the Var sample. More data, perhaps obtained from microsatellites and sequences in the same localities, is required to understand the origin of these two groups in the Var.

The populations of Var1 and Albera showed a relatively low $F_{S T}$ value and are more closely related to each other than to the Italian populations (Table A1B). This result is consistent with what is known of their history. Several Late Pleistocene and Holocene fossil deposits located in the French Mediterranean region indicate that the geographic distribution of $T$. $h$. hermanni covered most of the territory, extending to the Albera massif in the west (Cheylan, 1981). The populations in Catalonia and Provence probably began to become isolated during the Holocene

Table 2

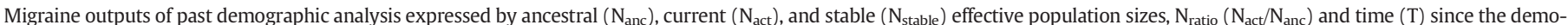

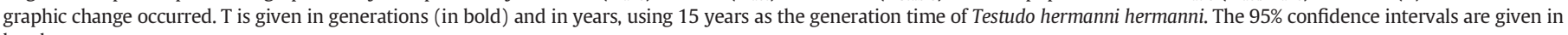
brackets.

\begin{tabular}{|c|c|c|c|c|c|c|c|}
\hline & Demographic event & $\mu$ & $\mathrm{N}_{\mathrm{anc}}$ & $\mathrm{N}_{\mathrm{act}}$ & $\mathrm{N}_{\text {stable }}$ & $\mathrm{N}_{\text {ratio }}$ & $\mathrm{T}$ \\
\hline \multirow[t]{2}{*}{ Albera } & Bottleneck & $\mu_{1}=0.0005$ & $5000[560-25,375]$ & $75[1-170]$ & - & $0.015[0.005-0.9]$ & $\begin{array}{l}\mathbf{1 2 6 0}[1-2448] \\
18,900[1-36,720]\end{array}$ \\
\hline & & $\mu_{2}=0.0015$ & $1667[187-8458]$ & 25 [1-57] & & & $\begin{array}{l}450[1-816] \\
6750[1-12,240]\end{array}$ \\
\hline \multirow[t]{2}{*}{ Corsica } & Expansion & $\mu_{1}=0.0005$ & $345[245-470]$ & $16,825\left[670-1.7 e^{7}\right]$ & - & $48.5[1.8-14,609]$ & $\begin{array}{l}\mathbf{1 3 . 4 6}[1-1884.4] \\
202[1-13,600]\end{array}$ \\
\hline & & $\mu_{2}=0.0015$ & 115 [82-156.6] & $5608\left[223-5.75 e^{6}\right]$ & & & $\begin{array}{l}4.5[1-628.13] \\
67.5[1-9422]\end{array}$ \\
\hline Ebro Delta & Stable & $\begin{array}{l}\mu_{1}=0.0005 \\
\mu_{2}=0.0015\end{array}$ & - & - & $\begin{array}{l}400[300-550] \\
133[100-183]\end{array}$ & - & - \\
\hline Var & Stable & $\begin{array}{l}\mu_{1}=0.0005 \\
\mu_{2}=0.0015\end{array}$ & - & - & $\begin{array}{l}200[150-280] \\
67[50-93]\end{array}$ & - & - \\
\hline Italy & Stable (expansion signal) & $\begin{array}{l}\mu_{1}=0.0005 \\
\mu_{2}=0.0015\end{array}$ & - & - & $\begin{array}{l}500[350-650] \\
167[116-217]\end{array}$ & - & - \\
\hline Minorca1 & Stable & $\begin{array}{l}\mu_{1}=0.0005 \\
\mu_{2}=0.0015\end{array}$ & - & - & $\begin{array}{l}300[200-400] \\
100[67-133]\end{array}$ & - & - \\
\hline Minorca2 & Stable (bottleneck signal) & $\begin{array}{l}\mu_{1}=0.0005 \\
\mu_{2}=0.0015\end{array}$ & - & - & $\begin{array}{l}150[100-250] \\
50[33-83]\end{array}$ & - & - \\
\hline Sardinia & Stable & $\begin{array}{l}\mu_{1}=0.0005 \\
\mu_{2}=0.0015\end{array}$ & - & - & $\begin{array}{l}500[400-750] \\
167[133-250]\end{array}$ & - & - \\
\hline Sicily & Stable (expansion signal) & $\begin{array}{l}\mu_{1}=0.0005 \\
\mu_{2}=0.0015\end{array}$ & - & - & $\begin{array}{l}500[350-750] \\
167[117-250]\end{array}$ & - & - \\
\hline
\end{tabular}



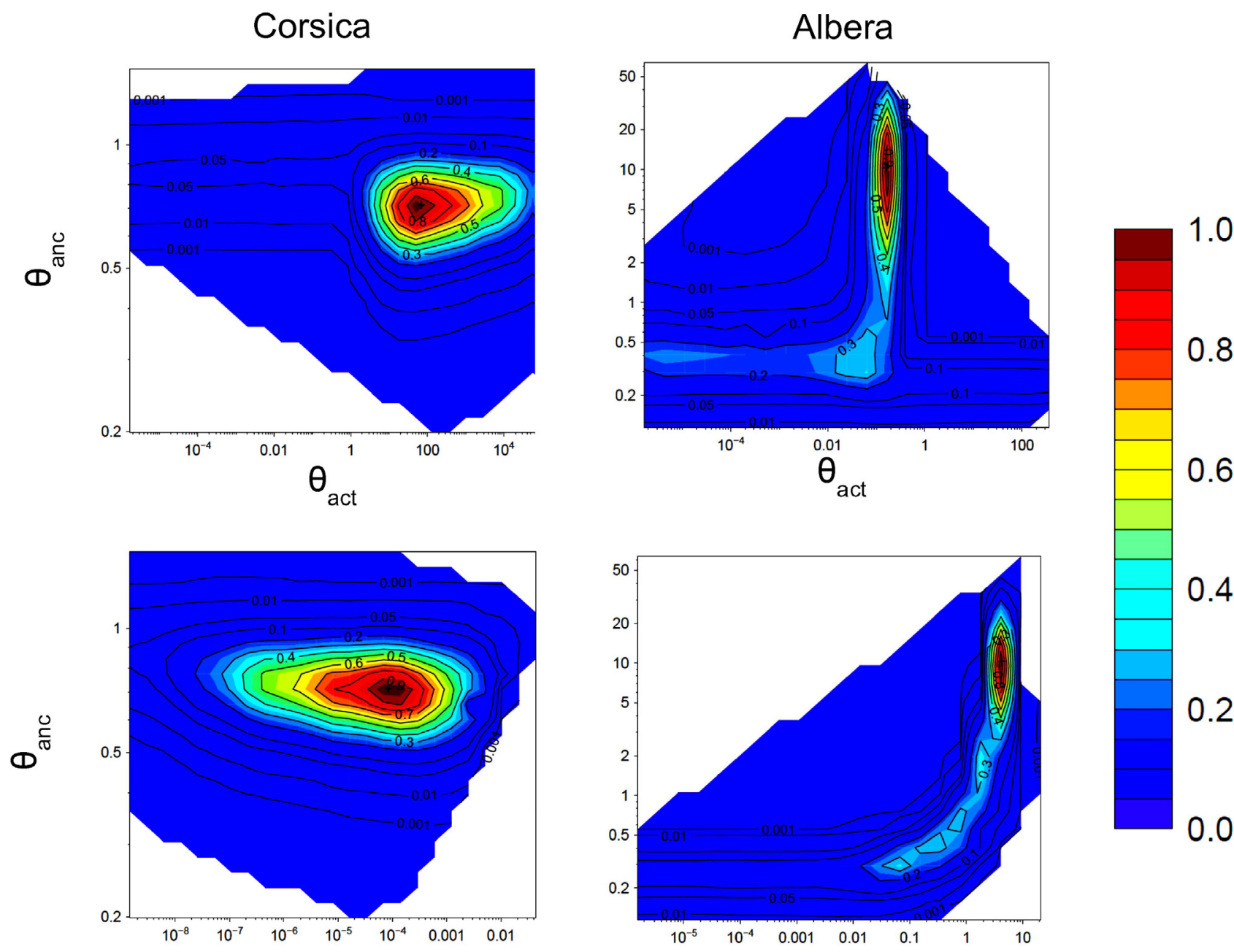

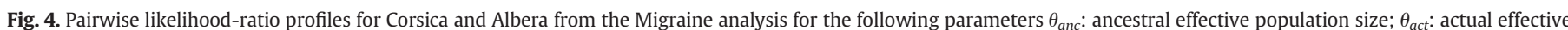

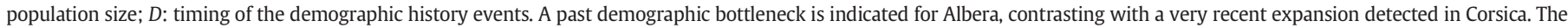

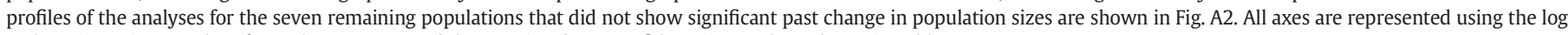
scale. Point estimate values for each parameter and the associated 95\% confidence interval are shown in Table 2.

(Forest and Cheylan, 2015). The populations of continental Italy, France and Spain likely shared a common ancestor at one point in their history as they constitute one cluster ( see $K=4$, Fig. $2 \mathrm{~A}$ ), which agrees with the fossil data. Perez et al. (2013) have hypothesized that the Var was colonized by tortoises of Italian origin. However, these three populations constitute three independent genetic units that are significantly differentiated (see $\mathrm{K}=8$, Fig. 2B). According to their genetic proximity, it is more probable that Var and Albera are two relictual populations that originated from the same glacial refugium - possibly located in the south of France or Catalonia. To confirm this hypothesis, more data is required (e.g. molecular dating, tests of evolutionary scenarios or tests of other molecular markers such as SNPs).

Although T. h. hermanni tortoises from continental Italy are found in three distant regions (from Tuscany to Puglia), all samples belong to the same rather homogeneous genetic group ( $K=8$ in Fig. $2 b)$. Compared to the other two continental populations (Albera and Var), the Italian genetic group presents the greatest genetic diversity (the highest number of alleles and heterozygosities; Table 1). This result is consistent with previous genetic studies (Van der Kuyl et al., 2002; Parham et al., 2006; Perez et al., 2013) that attest that the Italian peninsula acted as an effective refuge during the last glacial cycles. The presence of $T$. $h$. hermanni on the Italian peninsula appears to have been continuous throughout the Upper Paleolithic and Holocene periods (Morales Pérez and Sanchis Serra, 2009).

\subsubsection{The insular lineage: Corsica, Sardinia and Sicily}

The clustering analysis yielded an insular group (Fig. 2A) bringing together Corsica, Sardinia and Sicily. These three populations show equal levels of diversity ( $A P, A R, H_{o}$; Table 1$)$ that are substantially higher than in the continental Albera and Var, and are similar to those observed in Italy. Most theoretical as well as empirical studies (see Frankham, 1998; Frankham et al., 2009) predict that populations should display lower levels of genetic diversity on islands compared to mainland populations, but our data does not support this pattern. Species for which island populations have greater variation than on the mainland are often characterized by high dispersal ability (Frankham, 1998), but this hypothesis does not hold true for the Hermann's tortoise. It can be assumed that the species' genetic diversity was effectively much higher in mainland populations than in island populations when $T$. h. hermanni was continuously distributed on the continent from the Iberian to the Italian peninsula. Yet due to the reduction of the continental distribution range, a drastic decrease in genetic diversity probably occurred on the continent, whereas islands are likely to have been able to preserve much of their genetic diversity. According to 
this hypothesis, islands can thus now be considered as genetic sanctuaries with important conservation potential for the Hermann's tortoise, particularly in Corsica.

$F_{S T}$ values revealed that the Corsica as well as the Sicily + Sardinia population are highly differentiated from the continental populations (Albera, Var, Italy; Table A1), allowing the rejection of the hypothesis of recent colonization of the three islands from the neighboring continental populations. This result is also confirmed by the study of Fritz et al. (2006) based on cytochrome b sequences and showing that tortoises from Corsica, Sicily and Sardinia belong to the same lineage. Moreover, in a study based on the mitochondrial cytochrome b and control region genes, Giacalone et al. (2009) hypothesized that local extinction occurred in Corsica and Sardinia followed by a subsequent recolonization of tortoises probably originating from Sicily, either by natural oversea dispersal or translocation by humans. A study by Perez et al. (2013) validated this assumption, observing a strong genetic similarity between tortoises in Corsica and Sicily. However, our data does not support the hypothesis of lineage replacement in Corsica for the following two reasons: (1) samples from Sardinia and Sicily are much more closely related compared to Corsica, which is more distantly related (see Fig. 2B); (2) over all sampled populations, Corsica shows the largest number of private alleles (Table 1 ). These findings reinforce the theory of an ancient origin of Corsican tortoises that can thus be considered as an autochthonous lineage. On the other hand, our findings ( $F_{S T}$, clustering) clearly indicate high genetic similarity between the populations of Sardinia and Sicily, thus corroborating the hypothesis of the extinction of the original lineage in Sardinia followed by repopulation from Sicily. The study of chelonian fossils of the Castiglione (northern Corsica) deposit confirm the presence of Hermann's tortoise remains dating from the Middle Pleistocene (Hervet and Salotti, 2000), constituting strong evidence that Hermann's tortoise is native to Corsica, although the timing of the species' arrival is still unclear.

\subsubsection{Minorca populations}

Two distinct genetic lineages were identified in Minorca. The first is located in the western part of the island (Minorca1) and belongs to the continental lineage (Figs. 2A and A1). The strong significance of the $F_{I S}$ values for Minorca1 may be explained by a possible recent founder effect. This would suggest that Minorca1 is of recent origin, supporting the idea of human introduction, most likely from a missing continental population that is currently extinct. This assumption is consistent with the history of past commercial exchanges that occurred in the Mediterranean region, especially between Catalonia (NE Spain) and Minorca. The second lineage observed (Minorca2) is found exclusively in Minorca and is located in the eastern part of the island. According to the $F_{S T}$ values (Fig. A1), Minorca2 is more closely related to the insular lineage (Corsica + Sardinia + Sicily) than to the continental lineage. The inbreeding coefficient is also significant in Minorca2; however, it remains very weak compared to Minorca1. This could be explained by a much older founder effect, possibly reflecting a very ancient introduction or arrival to the island. The origin and arrival of the Minorca2 lineage remain unknown, but in view of the genetic divergence estimates $\left(F_{s t}\right.$, Table A1), it is currently difficult to settle on one of two hypotheses: that the population has an ancient autochthonous lineage or that it was introduced from an unknown insular lineage that is much older than that of Minorca1. There is evidence of the presence of Hermann's tortoise in the Balearic Islands during the Talayotic period (about 3000 BP) (Alcover and Mayol, 1981), which is compatible with a hypothesis of human introduction during the Neolithic period (Alcover et al., 1981). However, the tortoise remains found in Mallorca were not directly dated, so it is possible that they do not belong to the stratum that was dated (Alcover com. pers.; Bertolero, 2014b). Further study of Mallorca's tortoise populations would be crucial for a better understanding of the colonization scenarios of the Balearic Islands. It should be mentioned that some evidence of introduction already exists in Mallorca; for example, the study of Fritz et al. (2006) revealed the presence of continental and insular haplotypes based on Cyt b sequences.

Minorca2 belongs to a cluster that includes the reintroduced population of the Ebro Delta. The latter population is made up of released tortoises from the Balearic Islands and others from an unknown origin. The Ebro Delta population displays the highest proportion of introgression of all other populations and shows high genetic variability (AR: 3.9, Table 1), probably because the founder individuals provided alleles of various origins. The results suggest that captive tortoises from the Balearic Islands used for reintroduction programs in the Ebro Delta Natural Park mainly came from the southeast of Minorca. This finding, together with the differences found between the continental and insular lineages, does not corroborate the hypothesis suggesting that $T . h$. hermanni from Sicily could have contributed to the repopulation of the Spanish coast and the Mediterranean islands (Perez et al., 2013).

\subsection{Demographic history: congruence between genetic and demographic information?}

Our analysis of past demographic dynamics detected a significant change in the effective population sizes in only two populations: a demographic bottleneck for the Albera population and a demographic expansion in Corsica (Table 2, Fig. 4). However, the inference of the different model parameters appears globally imprecise, with large confidence intervals. These are likely due to the limited amount of information present in the genetic data. In Albera, the bottleneck signal represented in the two-dimension likelihood-ratio profile in Fig. 4 shows a high peak in the likelihood surface for high D values (around $2-8$ ), suggesting a relatively old contraction in population size. On one hand, considering this peak and the point estimate of the time since the demographic change, this analysis of the Albera population suggests that the contraction occurred approximately at the Last Glacial Maximum (around $19 \mathrm{kyr}$, considering a mutation rate of $\mu_{1}=5 \times 10^{-4}$ ). On the other hand, given the large confidence intervals, one cannot exclude a much more recent decrease in population size. In fact, the lower bound of the $\mathrm{Cl}$ does not allow the exclusion of a very recent contraction that occurred in the last generations/years. Thus the hypothesis that recent human impact has been preponderant in the process of population decline is not the strongest signal given by our Migraine analysis, but this cannot be completely rejected. Interestingly, the inference of the actual population size was more precise, suggesting a relatively low current population size. Given its geographical isolation, the Albera population thus seems exposed to a high risk of inbreeding depression. According to Frankham et al. (2014), a $N_{e} \geqslant 100$ is required to limit inbreeding depression to $10 \%$ over five generations. With $N_{\mathrm{e}}$ estimated at between 1 and $170(95 \% \mathrm{CI})$ for Albera, the effective population size falls within the threshold proposed by Frankham et al. as resulting in inbreeding depression. The estimated density available for this population shows a minimum of 3500 adults (Bertolero, 2010a). Thus, we note a marked difference between the effective population size (in the genetic sense) and the actual population size (in the demographic sense). This difference is higher than expected (which is often a factor of 10) (Frankham, 2007; Frankham et al., 2014). It is not possible at this stage to provide an explanation for this.

In contrast, our analyses suggest that a demographic expansion occurred in the Corsica population. This expansion may correspond to the period of high anthropic exploitation in the 19th and first half of the 20th century, during which the clearing of landscapes was favorable to Hermann's tortoise. However, the confidence interval proposed (1-13,600 years) does not allow the confirmation of this hypothesis.

For the other populations, our analyses did not detect any significant past demographic events. In some populations, the likelihood-ratio profiles correspond to perfectly stable populations with a $\Theta_{\text {stable }}$ value allowing the estimation of the stable effective size $N_{\text {stable }}$ (Ebro Delta, Var, Minorca1 and Sardinia, Fig. A2, Table 2). The remaining 
populations, for which we cannot reject a scenario of stability, do, however, show some signs of past changes in population size that were not strong enough or were too recent or old to be detected with the $17 \mathrm{mi}-$ crosatellite loci used in this study (an expansion signal in Italy and Sicily; a bottleneck in Minorca2; Table 2, Fig. A2).

The demographic data available for these populations shows contrasting recent demographic dynamics that were not demonstrated by the genetic analysis. In the genetic analysis, the Var population did not show signs of decline, even though it has been considerably reduced and fragmented over the course of the last century (Cheylan et al., 2009). In the same way, the Sicily population, whose genetic data indicates stability, or even expansion, is today found only in three extremely reduced and isolated patches, clearly showing a process of contraction in its distribution range on this island (Turrisi and Vaccaro, 2004). In contrast, the Minorca population, whose numbers were reduced in the 1970s and 1980s by intense agricultural exploitation, today shows strong expansion due to the abandonment of farmland, freeing up land that has been recolonized by the species (Bertolero, unpublished). The same goes for the population introduced to the Ebro Delta in 1987, which shows an annual growth rate of $2.5 \%$ as well as marked spatial expansion (Bertolero, 2002). The genetic information did not detect any expansion signals in either case. The results obtained for the populations of Sardinia (stable) and continental Italy (stable, expansion signal) also contradict what we know about the actual population dynamics (Mazzotti, 2004; Corti et al., 2013). Thus, the results must be interpreted with caution given the insufficiency of the genetic sample.

The weak apparent congruence between the genetic data and the demographic data has several explanations. The first is the generation time. The Hermann's tortoise has a long generation time of around 15 years, which is barely six generations a century. However, events less than 10-20 generations are difficult to detect with currently available methods (Leblois et al., 2014). Secondly, the number of microsatellite loci analyzed may not be sufficient and then has an effect on the ability to detect changes on a demographic scale. Taking this into account, it is not surprising that recent demographic changes were not detected for these populations, though they have been clearly shown by demographic monitoring or by empirical studies of the recent evolution of these populations.

The marked differences found between effective populations and actual censused populations can be surprising (the effective population size of the Var population is between 50 and 280 individuals, while the actual population size is more than 30,000 adult individuals (Cheylan et al., 2009). This divergence may be due to the weak dispersal ability of the Hermann's tortoise, leading to a strong local genetic structure. As a result, the estimated effective population may not express the effective population of the whole population, but only of the subgroup sampled for the genetic analysis (Leblois et al., 2006). Furthermore, one must take into account the CIs of the estimates, which are often very large, as shown in Table 2.

Given these divergences, it is important to interpret demographic information provided by genetic data with caution, particularly when considering operational data that will be used to define the conservation management of populations.

\subsection{Conservation issues}

In total, five genetic groups (Albera, mainland Italy, Minorca1, and the two genetic groups of the Var) have been identified as belonging to the continental lineage, whereas five others can be considered as belonging to the insular lineage (Minorca2, Sicily + Sardinia, and the three genetic clusters in Corsica). In order to adapt the conservation strategies for each of these $T$. h. hermanni populations and to remedy the alarming situation of some of them, our study aimed to identify the most relevant groups for conservation. Our analyses yielded different genetic lineages of $T$. h. hermanni on which specific ESUs (evolutionarily significant units; Moritz, 1994) and MUs (management units; Moritz, 1994) can be proposed.

\subsubsection{Evolutionarily significant units and management units for T. $h$. hermanni}

Many authors believe that genetically differentiated populations within species should not be treated together and require separate genetic management (see Moritz, 1994, 1995). These populations are referred to as evolutionarily significant units, as they represent an important part of the evolutionary legacy of the species. ESUs are defined as sets of populations showing reciprocal monophyly of mtDNA combined with significant divergence of allele frequencies at nuclear loci (Moritz, 1994). According to the high genetic differentiation among the inferred genetic clusters, our results strongly support three genetically isolated ESUs: (i) continental (Albera, Var, peninsular Italy and Minorca1); (ii) island 1 (Corsica, Sardinia and Sicily); and (iii) island 2 (Minorca2). Although we have the information about the reciprocal monophyly of the continental and island 1 ESUs based on the CytB gene (Fritz et al., 2006), a study with a larger number of mitochondrial markers should be carried out in order to verify the monophyly of the third ESU.

Because the populations of $T$. h. hermanni are fragmented geographically and the species' limited dispersal ability means these populations are isolated from each other, they can be considered as demographically independent. Hence, it is crucial to supplement ESUs with another type of conservation unit. Defining management units (MUs) is ideal for insitu management of natural populations that justifying distinct conservation and management strategies. These are populations that are important to conserve because they are entities connected by such a weak gene flow that they are functionally independent. Based on this definition and given their geographical isolation (with the exception of the two genetic groups of the Var), each genetic entity revealed by our study could be considered a separate MU. However, for management convenience, we propose six MUs for this species: (1) Albera + Minorca1; (2) Var; (3) Italy; (4) Sardinia + Sicily; (5) Corsica; and (6) Minorca2. These six genetic groups are isolated geographically, and their genetic uniqueness indicates that they should be considered as independent units. Traditionally, the Balearic populations of Hermann's tortoises have received little attention due to their assumed status as human-introduced fauna. However, as one of the lineages we found is actually exclusive to Minorca, we believe it needs to be regarded as a unit of high conservation value.

\subsubsection{Hybridization with T. h. boettgeri}

Since the last decades of the 20th century, translocations and illegal releases of tortoises are known to have been frequent, notably with regard to the Balkan subspecies T. $h$. boettgeri, which has been sold in large numbers as pets (Lambert, 1984). However, signs of admixture between $T$. h. hermanni and T. h. boettgeri are rather limited and seem to concern only continental populations, with the exception of Albera. Four introgressed tortoises (out of 31) were identified in the Ebro Delta, which is not really surprising since all animals released there were captive-bred. In Italy, three hybrids (out of 32) have been found, which may be explained by illegal introductions as these have been reported in many places (Mazzotti, 2004). In the Var, only five $T$. $h$. hermanni individuals (out of 81 ) have been detected with T. h. boettgeri alleles, thus revealing less introgression than may have been expected given the numerous releases that have taken place (Cheylan et al., 2009). One noteworthy point is that no cases of hybridization between T. h. hermanni and T. h. boettgeri have been detected on the four studied islands, suggesting that translocations were less frequent there than on the continent. However, in Corsica some samples have been identified with alleles originating from Sardinia. It can be presumed that they likely result from human translocations. 


\subsubsection{Practical recommendations}

This study has allowed us to genetically identify almost all the occidental populations of T. h. hermanni. We could therefore use genetics to identify captive or collected animals that could potentially be used in translocation programs. In particular, in order to prevent the Albera population from suffering the same fate as its neighboring population on the French side of the border (which completely disappeared in the 1960s), a compromise would be to reinforce this population with individuals from Minorca1 or Var, which have been identified as the genetically closest populations (see Table A1). Many reintroduction projects that have been carried out in Catalonia and the region of Valencia have involved tortoises from Minorca, but there has never been any control or genetic identification of the released individuals. Before carrying out releases in natural environments, the genetic identification of individuals needs to be performed in order to avoid potential problems linked to outbreeding depression (loss of local adaptation, genetic incompatibility and gene disruption through chromosomal differences), whose effects are expressed from the first generations. Moreover, the genetic monitoring of individuals involved in breeding programs is also essential to prevent inbreeding caused by incorporating new alleles issuing from genetically close individuals.

As is the case for several Spanish populations, new populations consisting of released captive tortoises and/or tortoises of unknown origin can be introduced a few hundred kilometers away from natural populations and be managed independently of the previously defined MUs. In general, these heterogeneous populations are useful for the conservation of the species as they expand its distribution range. Furthermore, because of their isolation from natural populations, introduced populations could be used as release sites for captive tortoises that have not been accepted in reinforcement projects (following the required genetic and sanitary controls).

Our recommendation for future reintroduction programs is to genetically select all released individuals to ensure they belong to the same ESU as the natural population of the region where the reintroduction will take place.

\section{Conclusion}

Using fairly exhaustive sampling and a high number of specific and polymorphic microsatellite markers, this study allowed identify three main genetic lineages among the subspecies T. h. hermanni in the occidental Mediterranean basin: one continental and two island lineages. Moreover, the genetic uniqueness of the $T$. $h$. hermanni populations within each geographic region reflects a very strong genetic structure. As a result of our findings, we are able to propose six management units as the most relevant for conservation purposes. Although the origin of the two lineages detected in Minorca remains speculative, one (Minorca2) is actually exclusive to this island. We also confirmed that of the three genetic groups found in Corsica, two are very different from the Sardo-Sicilian group, leading us to conclude that the lineage actually present in Corsica is autochthonous. Using demographic history analyses, we found evidence to indicate that the bottleneck detected in the Spanish Albera was very old and severe.

Taken together, these results allow us to conclude that rigorous monitoring of genetic breeding programs already in place is essential to avoid problems associated with inbreeding depression. One solution would be to incorporate new alleles in a population by the release of individuals from genetically related populations. Finally, our work highlights the need to further study the impact of landscape and landscape changes (as a barrier to gene flow) on the fine genetic structure of each population. Indeed, the minority lineage observed in the Var suggests that the full range of genetic diversity of $T$. $h$. hermanni has not yet been evidenced. In particular, captive individuals kept as pets deserve more attention in revealing the whole genetic complexity of the species. Lastly, our results could be taken into account in future reinforcement programs and used to help identify the genetic membership of captive individuals to be released.

\section{Acknowledgments}

This study was supported by the Foundation for Research on Biodiversity (FRB: Fondation pour la Recherche sur la Biodiversité) with CORSEPYR project funding (AAP-IN-2009-15). The French National Action Plan (PNA: Plan National d'Action) financed the sample-collecting field work and partly funded the production of molecular data [French ministery of ecology grants (DREAL-PACA): CNRS contract $n^{\circ} 077100$ in 2013 and CNRS contract $n^{\circ} 131759$ in 2014]. The regional governments of Catalonia and the Balearic Islands (Generalitat of Catalonia and the Govern de les Illes Balears) authorized our scientific work. Field work in the Ebro Delta, the Albera and Minorca was partially funded by the Ebro Delta Natural Park, the Generalitat de Catalunya, the Institut Menorquí d'Estudis (IME) and the Spanish Ministry of Science and Technology (CICYT CGL2004-0473/BOS). All molecular data were generated at the technical facility of the Mediterranean Center of the Environment and Biodiversity (CeMEB: Centre Méditerranéen de l'Environnement et de la Biodiversité) in Montpellier, France. Microsatellite genotyping was carried out at the MBB platform of the CeMEB LabEx laboratory in Montpellier. The Migraine analysis was carried out using the MIGALE and GenoToul bioinformatics platforms at the French National Institute of Agronomic Research (INRA: Institut National de la Recherche Agronomique) and the computing grids of the Center of Biology for Population Management (CBGP: Centre de Biologie pour la Gestion des Populations) laboratory.

\section{Appendix A. Supplementary data}

Supplementary data to this article can be found online at http://dx. doi.org/10.1016/j.biocon.2016.01.007.

\section{References}

Alcover, J., Mayol, J., 1981. Espècies relíquies d'amfibis i de rèptils a les Balears i Pitiüses. Bol. Soc. Hist. Nat. Baleares 25, 151-167.

Alcover, J.A., Casasnovas, G.C., Moyà-Solà, S., Moyà, J.P., 1981. Les Quimeres del Passat: Els Vertebrats Fòssils del Plio-Quaternari de les Balears i Pitiüses. Moll.

Araújo, M.B., Thuiller, W., Pearson, R.G., 2006. Climate warming and the decline of amphibians and reptiles in Europe. J. Biogeogr. 33, 1712-1728.

Austin, J.D., Gorman, T.A., Bishop, D., Moler, P., 2011. Genetic evidence of contemporary hybridization in one of North America's rarest anurans, the Florida bog frog. Anim. Conserv. 14 (5), 553-561.

Beaumont, M.A., 1999. Detecting population expansion and decline using microsatellites. Genetics 153 (4), 2013-2029.

Bertolero, A., 2010a. Cens i distribució de la tortuga mediterrània a la serra de l'Albera. Avaluació de la situació durant 2010. Unpublished report to Ministry of the Environment and Housing. Government of Catalonia.

Bertolero, A., 2002. Biología de la tortuga mediterránea Testudo hermanni aplicada a su conservación. PhD thesis, Universitat de Barcelona, Barcelona.

Bertolero, A., 2010b. Tortuga mediterránea Testudo hermanni. In: Salvador, A., Marco, A (Eds.), Enciclopedia Virtual de los Vertebrados Españoles. Museo Nacional de Ciencias Naturales, Madrid (http://www.vertebradosibericos.org/).

Bertolero, A., 2014a. Statut, répartition actuelle et réintroduction de la Tortue d'Hermann en Espagne. Chelonii 9, 35-40.

Bertolero, A., 2014b. Testudo hermanni Gmelin, 1789. In: Ramos, M.A., et al. (Eds.), Fauna Ibérica, vol. 10, 2nd edición Reptiles. Museo Nacional de Ciencias Naturales. CSIC, Madrid, pp. 217-236 (In: Salvador, A. (Coordinador) revisada y aumentada).

Bertolero, A., Oro, D., Besnard, A., 2007. Assessing the efficacy of reintroduction programmes by modelling adult survival: the example of Hermann's tortoise. Anim. Conserv. 10, 360-368.

Bertolero, A., Cheylan, M., Hailey, A., Livoreil, B., Willemsen, R.E., 2011. Testudo hermanni (Gmelin 1789)-Hermann's tortoise. Conservation biology of freshwater turtles and tortoises: a compilation project of the IUCN/SSC tortoise and freshwater turtle specialist group Chelon. Res. Monogr. 5, 070-071.

Böhm, M., Collen, B., Baillie, J.E., Bowles, P., Chanson, J., Cox, N., Cheylan, M., et al., 2013. The conservation status of the world's reptiles. Biol. Conserv. 157, 372-385.

Bouzat, J.L., 2010. Conservation genetics of population bottlenecks: the role of chance, selection, and history. Conserv. Genet. 11, 463-478.

Budó, J., Capalleras, X., Fèlix, J., Mascort, R., 2004. La Tortuga Mediterrània (Testudo hermanni) a l'Albera: Causes de Regressió, Estat Actual de les Poblacions i Perspectives de Futur. Colloqui Internacional l'Albera i el Patrimoni en l'espai Transfronterer (www.tortugues.cat/pdf/05_tortuga_mediterranea.pdf).

Casas-Marce, M., Soriano, L., López-Bao, J.V., Godoy, J.A., 2013. Genetics at the verge of extinction: insights from the Iberian lynx. Mol. Ecol. 22 (22), 5503-5515. 
Celse, J., Catard, A., Caron, S., Ballouard, J.M., Gagno, S., Jardé, N., Cheylan, M., Astruc, G., Croquet, V., Bosc, V., Petenian, F., 2014. Guide de gestion des populations et des habitats de la tortue d'Hermann. Life 08 NAT/000475. ARPE PACA.

Cheylan, M., 1981. Biologie et écologie de la tortue d'Hermann Testudo hermanni Gmelin 1789. Contribution de l'Espèce a la Connaissance des Climats Quaternaires de la France 13. Ecole Pratique des Hautes Etudes, Mémoires et Travaux de l'Institut de Montpellier (404 p).

Cheylan, M., 1984. The true status and future of Hermann's tortoise Testudo hermanni robertmertensi Wermuth 1952 in Western Europe. Amphibia-Reptillia 5, 17-26.

Cheylan, M., 1995. Les tortues d'Hermann et cistude en Corse. Situation actuelle et mesures de sauvegarde. In: Ballasina, D. (Ed.), Red Data Book on Mediterranean Chelonians. Edagricola, Bologna, pp. 69-93.

Cheylan, M., 2001. Testudo hermanni Gmelin, 1789-Griechische Landschi-Idkröte. Handbuch der Reptilien und Amphibien Europas. 3, pp. 179-289.

Cheylan, M., 2004. Incendies: lourd tribu pour les tortues d'Hermann. Espace Naturels 5, 10.

Cheylan, M., Catard, A., Livoreil, B., Bosc, V., 2009. Plan national d'actions tortue d'Hermann. (http://webissimo.developpement-durable.gouv.fr/IMG/pdf/pna_thh_ 2009_2014_web_cle01fbf7.pdf).

Cheylan, M., Corti, C., Carpaneto, G.M., Mazzotti, S., Zuffi, M., 2011. Testudo hermanni Gmelin, 1789: 188-199. In: Corti, C., Capula, M., Luiselli, L., Razzetti, E., Sindaco, R. (Eds.), Fauna d'Italia, Reptilia. Edizioni Calderini de Il Sole 24 ORE Editoria Specializzata S.r.l., Bologna.

Collins, J.P., Storfer, A., 2003. Global amphibian declines: sorting the hypotheses. Divers. Distrib. 9 (2), 89-98.

Corander, J., Marttinen, P., Sirén, J., Tang, J., 2008. Enhanced Bayesian modelling in BAPS software for learning genetic structures of populations. BMC Bioinf. 9, 539.

Corti, C., Biaggini, M., Bassu, L., Di Cerbo, A.R., Di Tizio, L., Lo Cascio, P., Mastropasqua, F., Nulchis, V., Romano, A., Satta, M.G., Sillero, N., 2013. Indagine Sullo Status delle Popolazioni Naturali di Testuggini Terrestri (Genere Testudo) in Italia, Relazione Finale. Ministero dell'Ambiente e della Tutela del Territorio e del Mare.

Couturier, T., Cheylan, M., Guérette, E., Besnard, A., 2011. Impacts of a wildfire on the mortality rate and small-scale movements of a Hermann's tortoise Testudo hermanni hermanni population in southeastern France. Amphibia-Reptilia 32 (4), 541-545.

Couturier, T., Besnard, A., Bertolero, A., Bosc, V., Astruc, G., Cheylan, M., 2014. Factors determining the abundance and occurrence of Hermann's tortoise Testudo hermanni in France and Spain: fire regime and landscape changes as the main drivers. Biol. Conserv. 170, 177-187.

De Lorio, M., Griffiths, R.C., 2004a. Importance sampling on coalescent histories. Adv. Appl. Probab. 36, 417-433.

De Lorio, M., Griffiths, R.C., 2004b. Importance sampling on coalescent histories. II. Subdivided population models. Adv. Appl. Probab. 36, 434-454.

De Lorio, M., Griffiths, R.C., Leblois, R., Rousset, F., 2005. Stepwise mutation likelihood computation by sequential importance sampling in subdivided population models. Theor. Popul. Biol. 68, 41-53.

Delfino, M., Bailon, S., 2000. Early Pleistocene herpetofauna from Cava dell'Erba and Cava Pirro (Apulia, Southern Italy). Herpetol. J. 10 (3), 95-110.

Delfino, M., Chesi, F., 2008. A critical overview of the fossil record and its bearing on the origin of the extant Italian tortoises. Herpetologia Sardiniae, Edizioni Belvedere. Societas Herpetologica Italica,"le scienze 8, pp. 188-191.

DeSalle, R., Amato, G., 2004. The expansion of conservation genetics. Nat. Rev. Genet. 5 (9), 702-712.

Devaux, B., 1990. Réintroduction de tortues d'Hermann (Testudo hermanni hermanni) dans le massif des Maures. J. Ecol. (Terre et Vie) S5, 291-297.

Devaux, B., Stubbs, D., 1997. Species recovery programme for Hermann's tortoise in Southern France. In: Van Abbema, J. (Ed.), Proceedings Conservation, Restoration, and Management of Tortoises and Turtles. New York Turtle and Tortoise Society, New York, pp. 330-332.

European Reptile, Amphibian Specialist Group, 1996. Testudo hermanni ssp. hermanni. The IUCN Red List of Threatened Species 1996: e.T21650A9306703. (http://dx.doi.org/10. 2305/IUCN.UK.1996.RLTS.T21650A9306703.en downloaded on 01 December 2015).

Evanno, G., Regnaut, S., Goudet, J., 2005. Detecting the number of clusters of individuals using the software STRUCTURE: a simulation study. Mol. Ecol. 14, 2611-2620.

Faith, D.P., 2008. Phylogenetic diversity and conservation. In: Carroll, S.P., Fox, C.W. (Eds.), Conservation Biology: Evolution in Action. Oxford Univ. Press, Oxford, pp. 85-98.

Forest, V., Cheylan, M., 2015. Les lièvres, les tortues et l'aurochs: une histoire archéozoologique en Languedoc-Roussillon. In: Tranoy, L., Bardot, A. (Eds.), l'Environnement en Mémoire, Marqueurs, Outils et Perspectives. Presses Universitaires de Rennes, pp. 25-43.

Forlani, A., et al., 2005. Identification and characterization of microsatellite markers in Hermann's tortoise (Testudo hermanni, Testudinidae). Mol. Ecol. Notes 5, 228-230.

Frankham, R., 1998. Inbreeding and extinction: island populations. Conserv. Biol. 12, 665-675.

Frankham, R., 2007. Effective population size/adult population size ratios in wildlife: a review. Genet. Res. 89 (Spec. Issue 5-6), 491-503.

Frankham, R., Ballou, J.D., Briscoe, D.A., 2009. Introduction to Conservation Genetics. second ed. Cambridge Uinversity Press, Cambridge (UK) (618 pp., of Frankham (2010)).

Frankham, R., 2010. Where are we in conservation genetics and where do we need to go? Conserv. Genet. 11 (2), 661-663.

Frankham, R., Bradshaw, C.J., Brook, B.W., 2014. Genetics in conservation management: revised recommendations for the 50/500 rules, Red List criteria and population viability analyses. Biol. Conserv. 170, 56-63.

Freeland, J.R., Kirk, H., Petersen, S., 2011. Molecular Ecology. second ed.
Fritz, U., et al., 2006. A rangewide phylogeography of Hermann's tortoise, Testudo hermanni (Reptilia: Testudines: Testudinidae): implications for taxonomy. Zool. Scr. 35, 531-543.

Funk, W.C., Tallmon, D.A., Allendorf, F.W., 1999. Small effective population size in the long-toed salamander. Mol. Ecol. 8 (10), 1633-1640.

Giacalone, G., Lo Valvo, M., Fritz, U., 2009. Phylogeographic link between Sicilian and Corso-Sardinian Testudo H. hermanni confirmed. Acta Herpetol. 4, 119-123.

Goudet, J., 2001. FSTAT, A Program to Estimate and Test Gene Diversities and Fixation Indices (Version 2.9. 3).

Hervet, S., Salotti, M., 2000. Les tortues pléistocènes de Castiglione (Oletta, Haute-Corse) et la preuve de leur indigénat en Corse. C. R. Acad. Sci., Ser. IIA: Earth Planet. Sci. 330 (9), 645-651.

Kamath, P.L., Haroldson, M.A., Luikart, G., Paetkau, D., Whitman, C., Manen, F.T., 2015 Multiple estimates of effective population size for monitoring a long-lived vertebrate: an application to Yellowstone grizzly bears. Mol. Ecol. 24 (22), 5507-5521.

Kotsakis, T., 1980. Anfibi e rettili del Plio-Pleistocene. I Vertebrati Fossili Italiani ||, Verona (Catalogo della Mostra).S, pp. 205-208.

Lambert, M.R., 1984. Threats to Mediterranean (West Palaearctic) tortoises and their effects on wild populations: an overview. Amphibia-Reptilia 5 (1), 5-15.

Langella, O., 1999. Populations v1.2.28 (12/5/2002): a population genetic software. CNRS UPR9034. Available at http://www.pge.cnrs-gif.fr/bioinfo/populations/index.php.

Leblois, R., Estoup, A., Streiff, R., 2006. Genetics of recent habitat contraction and reduction in population size: does isolation by distance matter? Mol. Ecol. 15 (12), 3601-3615.

Leblois, R., Pudlo, P., Néeron, J., et al., 2014. Maximum-likelihood inference of population size contractions from microsatellite data. Mol. Biol. Evol. 31, 2805-2823.

Llorente, G.A., Montori, A., Carretero, M.A., Santos, X., 2002. Testudo hermanni (Gmelin, 1789). Tortuga mediterránea. In: Pleguezuelos, J.M., Márquez, R. Lizana, M. (Eds.), Atlas y libro rojo de los Anfibios y Reptiles de España. Madrid: Dirección general de Conservación de la Naturaleza - Asociación Herpetologica Española 151-153.

Lozier, J.D., 2014. Revisiting comparisons of genetic diversity in stable and declining species: assessing genome-wide polymorphism in North American bumble bees using RAD sequencing. Mol. Ecol. 23, 788-801.

Mascort, R., 1997. Land tortoises in Spain: their status and conservation. Proceedings Conservation, Restoration and Management of Tortoises and Turtles, New York. New York Turtle and Tortoise Society, pp. 307-312.

Mazzotti, S., 2004. Hermann's tortoise (Testudo hermanni): current distribution in Italy and ecological data on a population from the north Adriatic coast (Reptilia, Testudinidae). Bull. Zool. 71 (S1), 97-102.

Morales Pérez, J.V., Sanchis Serra, A., 2009. The Quaternary fossil record of the genus Testudo in the Iberian Peninsula. Archaeological implications and diachronic distribution in the western Mediterranean. J. Archaeol. Sci. 36, 1152-1162.

Moritz, C., 1994. Defining 'evolutionarily significant units' for conservation. Trends Ecol. Evol. 9 (10), 373-375.

Moritz, C., 1995. Uses of molecular phylogenies for conservation. Philos. Trans. R. Soc. B 349 (1327), 113-118.

Nei, M., 1978. Estimation of average heterozygosity and genetic distance from a small number of individuals. Genetics 89 (3), 583-590.

Parham, J.F., et al., 2006. The phylogeny of Mediterranean tortoises and their close relatives based on complete mitochondrial genome sequences from museum specimens. Mol. Phylogenet. Evol. 38, 50-64.

Peakall, R., Smouse, P.E., 2006. GENALEX 6: genetic analysis in Excel. Population genetic software for teaching and research. Mol. Ecol. Notes 6, 288-295.

Peery, M.Z., et al., 2012. Reliability of genetic bottleneck tests for detecting recent population declines. Mol. Ecol. 21, 3403-3421.

Perez, M., et al., 2013. Genetic variation and population structure in the endangered Hermann's tortoise: the roles of geography and human-mediated processes. J. Hered. 105, 70-81.

Phillipsen, I.C., Funk, W.C., Hoffman, E.A., Monsen, K.J., Blouin, M.S., 2011. Comparative analyses of effective population size within and among species: ranid frogs as a case study. Evolution 65 (10), 2927-2945.

Pritchard, J.K., Stephens, M., Donnelly, P., 2000. Inference of population structure using multilocus genotype data. Genetics 155, 945-959.

Rousset, F., 2008. GENEPOP'007: a complete re-implementation of the GENEPOP software for Windows and Linux. Mol. Ecol. Resour. 8, 103-106.

Santos, X., Cheylan, M., 2013. Taxonomic and functional response of a Mediterranean reptile assemblage to a repeated fire regime. Biol. Conserv. 168, 90-98.

Shaffer, H.B., Gidiş, M., McCartney-Melstad, E., Neal, K.M., Oyamaguchi, H.M., Tellez, M. Toffelmier, E.M., 2015. Conservation genetics and genomics of amphibians and reptiles. Annu. Rev. Anim. Biosci. 3 (ch_1), 113-138.

Smith, T.B., Grether, G.F., 2008. The importance of conserving evolutionary processes. In: Carroll, S.P., Fox, C.W. (Eds.), Conservation Biology: Evolution in Action. Oxford Univ. Press, Oxford, pp. 85-98.

Soulé, M.E., 1985. What is conservation biology? A new synthetic discipline addresses the dynamics and problems of perturbed species, communities, and ecosystems, BioScience 35 (11), 727-734.

Sun, J.X., Helgason, A., Masson, G., et al., 2012. A direct characterization of human mutation based on microsatellites. Nat. Genet. 44, 1161-1165.

Turrisi, G.F., Vaccaro, A., 2004. Status and conservation of herpetofauna from the Iblean area (south eastern Sicily). Ital. J. Zool. 71 (2), 185- : 189.

UICN France, MNHN, SHF, 2015. La Liste Rouge des Espèces Menacées en France. Chapitre Reptiles et Amphibiens de France Métropolitaine, Paris.

Van der Kuyl, A.C., et al., 2002. Phylogenetic relationships among the species of the genus Testudo (Testudines: Testudinidae) inferred from mitochondrial 12S rRNA gene sequences. Mol. Phylogenet. Evol. 22, 174-183. 
Van Oosterhout, C., Hutchinson, W.F., Wills, D.P.M., Shipley, P., 2004. Micro-checker: software for identifying and correcting genotyping errors in microsatellite data. Mol. Ecol. Notes 4, 535-538.

Vasconcelos, R., Brito, J.C., Carvalho, S.B., Carranza, S., Harris, D.J., 2012. Identifying priority areas for island endemics using genetic versus specific diversity-the case of terrestrial reptiles of the Cape Verde Islands. Biol. Conserv. 153, 276-286.

Velo-Antón, G., Wink, M., Schneeweiß, N., Fritz, U., 2011. Native or not? Tracing the origin of wild-caught and captive freshwater turtles in a threatened and widely distributed species (Emys orbicularis). Conserv. Genet. 12 (2), 583-588.

Vilardell, A., Capalleras, X., Budó, J., Molist, F., Pons, P., 2012. Test of the efficacy of two chemical repellents in the control of Hermann's tortoise nest predation. Eur. J. Wildl. Res. 54, 745-748.

Von der Heyden, S., Beger, M., Toonen, R.J., van Herwerden, L., Juinio-Meñez, M.A., Ravago-Gotanco, R., Bernardi, G., 2014. The application of genetics to marine management and conservation: examples from the Indo-Pacific. Bull. Mar. Sci. 90 (1) 123-158.

Weir, B.S., Cockerham, C.C., 1984. Estimating F-statistics for the analysis of population structure. Evolution 1358-1370.
Welton, L.J., Siler, C.D., Linkem, C.W . Diesmos, A.C. Diesmos, M.L., et al, 2013. Dragons in our midst: phyloforensics of illegally traded Southeast Asian monitor lizards. Biol. Conserv. 159, 7-15.

Wermuth, H., 1952. Testudo hermanni robertmertensi n. subsp. Und ihr Vorkommen in Spanien. Senckenbergiana 33, 157-164.

Winter, M., Devictor, V., Schweiger, O., 2013. Phylogenetic diversity and nature conservation: where are we? Trends Ecol. Evol. 28 (4), 199-204.

Witzenberger, K.A. Hochkirch A 2011. Ex situ conservation genetics: a review of molecular studies on the genetic consequences of captive breeding programmes for endangered animal species. Biodivers. Conserv. 20 (9), 1843-1861.

Wright, S., 1978. The relation of livestock breeding to theories of evolution. J. Anim. Sci. 46 (5), 1192-1200.

Young, A.G., Clarke, G.M., 2000. Genetics, Demography and Viability of Fragmented Populations vol. 4. Cambridge University Press.

Zhang, D.X., Hewitt, G.M., 2003. Nuclear DNA analyses in genetic studies of populations: practice, problems and prospects. Mol. Ecol. 12 (3), 563-584. 